Article

\title{
Acylated Flavone $O$-Glucuronides from the Aerial Parts of Nepeta curviflora
}

\author{
Maysaa Rabee ${ }^{1}$, Øyvind Moksheim Andersen ${ }^{2}$, Torgils Fossen ${ }^{2}$, Kjersti Hasle Enerstvedt ${ }^{2}$, \\ Hijazi Abu Ali ${ }^{1}$ and Saleh Rayyan ${ }^{1, *(D)}$ \\ 1 Department of Chemistry, Birzeit University, Birzeit 627, Palestine; maysa.rabee@hotmail.com (M.R.); \\ habuali@birzeit.edu (H.A.A.) \\ 2 Department of Chemistry and Centre for Pharmacy, University of Bergen, Allégt. 41, \\ N-5007 Bergen, Norway; oyvind.andersen@uib.no (Ø.M.A.); torgils.fossen@uib.no (T.F.); \\ kjersti.enerstvedt@uib.no (K.H.E.) \\ * Correspondence: sarayyan@birzeit.edu; Tel.: +970597586124; Fax: +97022982084
}

Academic Editor: Natalizia Miceli

Received: 3 July 2020; Accepted: 11 August 2020; Published: 20 August 2020

\begin{abstract}
Nepeta curviflora Boiss. (Syrian catnip) is native to the Middle East. This medicinal plant is commonly used against nervous disorders, rheumatic pains, and high blood pressure. Herbal infusions prepared from various Nepeta spp. are extensively consumed as functional food. However, limited information has been known about the phenolic constituents of Syrian catnip. In this study, two acylated flavone 7-O-glucuronides, apigenin 7-O-(2"-O( $2^{\prime \prime \prime}$-(E-caffeoyl)- $\beta$-glucuronopyranosyl)- $\beta$-glucuronopyranoside) (1) and luteolin 7-O-(2"-O-(2'"(E-caffeoyl)- $\beta$-glucuronopyranosyl)- $\beta$-glucuronopyranoside) (2), along with the known phenolic compounds rosmarinic acid, caffeic acid, apigenin, and apigenin $7-O-\beta$-glucopyranoside were isolated from the aerial parts of $N$. curviflora. The characterizations of these compounds were based on high-resolution mass spectrometry, $\mathrm{UV}$, and extensive use of multidimensional NMR spectroscopy. The new compounds ( $\mathbf{1}$ and $\mathbf{2})$ were identified in the unmodified state and as dimethylesters.
\end{abstract}

Keywords: syrian catnip; Nepeta curviflora; lamiaceae; acylated flavone 7-O-glucuronosides

\section{Introduction}

The genus Nepeta (Lamiaceae) is widely distributed in Europe, North Africa, North America, India, and Asia, including the Mediterranean countries. It contains around 300 species, some of which are used in traditional medicine [1]. Intake of some Nepeta spp. has been associated with positive health effects, including antispasmodic, antiasthmatic, and anti-inflammatory activities, as well as efficiently maintaining and balancing serum lipids [2-5]. Some species (for instance Nepeta menthoides) have also been used as traditional herbal medicine against nervous disorders, rheumatic pains, and high blood pressure [6], while the aqueous extracts of N. menthoides have possible benefits in controlling the mood of patients suffering from major depression [7]. As a consequence, herbal infusions prepared from Nepeta spp. are nowadays considered as functional food [8].

The potential beneficial pro-health effects associated with the intake of Nepeta species have been suggested to be partly attributable to their content of essential oils and phenolic compounds [1,9-16], which have been reported as the major secondary metabolites of this genus [16-18]. Among these, rosmarinic acid appears to be the most abundant phenolic compound [1,17,19-22].

Syrian catnip, N. curviflora Boiss., (syn. Glechoma curviflora (Boiss.) Kuntze), a medicinal plant native to the Middle East, has been reported to exhibit antioxidant [23], phytotoxic [24] as well as nematicidal activities [25]. While the screened antimicrobial activity of dimethylsulfoxide extract of N. curviflora apparently is low [26], however, methanolic extracts of leaves and stem of this plant have shown 
efficacy against more than $88.8 \%$ of the tested microorganisms [26]. Only volatile chemical constituents have previously been reported from N. curviflora [24-27]. Although phenolic compounds of some Nepeta spp. have been suggested to be responsible for a wide range of biological activities [20,28,29], the specific characterization of this group of phenolic compounds appears underinvestigated in this genus. The aim of this study was thus to isolate and elucidate individual phenolic constituents of the aerial parts of Syrian catnip.

\section{Results and Discussion}

The plant was identified by Dr. Munir Naser at Birzeit University, and a voucher specimen of N. curviflora has been deposited at Al-Quds University Herbarium (accession number Nc2019Lam11) and at the seeds bank of the Union of Agricultural Work Committees (UAWC) (accession number UB-435-19/s).

The HPLC chromatogram of the methanolic extract of the aerial parts (stems, leaves, and flower) of $N$. curviflora recorded at $360 \mathrm{~nm}$ showed two major and several minor compounds. This extract was purified by partition against hexane, followed by Amberlite XAD-7 absorption chromatography. The flavonoids in the purified extract were further fractionated by Sephadex LH-20 chromatography, and pure compounds $(\mathbf{1}, \mathbf{2}$, and $\mathbf{4})$ were thereafter isolated by preparative HPLC of selected Sephadex LH-20 fractions.

Compounds 3 and 4 were identified as the methylesters of the known phenolic compounds rosmarinic acid and caffeic acid, respectively (Tables S1 and S2, supplementary materials). The esters were most probably made by the solvent (acidified methanol) during isolation. Compounds 5 and $\mathbf{6}$ were isolated from the flowers of the plant and identified as apigenin (5) and apigenin 7-O- $\beta$-glucopyranoside (6) by UV (Table S1) and NMR (Table S3) spectroscopy.

The downfield region of the ${ }^{1} \mathrm{H}-\mathrm{NMR}$ spectrum of $\mathbf{1}$ (Figure S1) showed an $\mathrm{AA}^{\prime} \mathrm{XX}$ ' system at $\delta 7.94\left(\mathrm{H}-2^{\prime} / 6^{\prime}\right)$ and $\delta 6.95\left(\mathrm{H}-3^{\prime} / 5^{\prime}\right)$, a one proton singlet at $\delta 6.85(\mathrm{H}-3)$ and an AX system at $\delta 6.76(\mathrm{~d}, J=2.2 \mathrm{~Hz} ; \mathrm{H} 8)$ and $\delta 6.39(\mathrm{~d}, J=2.2 \mathrm{~Hz} ; \mathrm{H} 6)$, in accordance with a 7-O-substituted apigenin derivative (Tables S1 and S3). Based on HSQC (Figure S3), HMBC (Figure S4), and H2BC (heteronuclear 2-bond correlation) (Figure S6) NMR spectra of 1, 15 carbon resonances belonging to the aglycone and 9 resonances corresponding to an acyl moiety, were assigned (Table 1). The presence of two glycopyranosyl units was further suggested from both the ${ }^{1} \mathrm{H}$ and ${ }^{13} \mathrm{C}-\mathrm{NMR}$ spectra (Table 1). The relationships between the ${ }^{1} \mathrm{H}$ sugar resonances of each sugar unit were assigned by the ${ }^{1} \mathrm{H}-{ }^{1} \mathrm{H}$ COSY experiment (Figure S7), and the corresponding ${ }^{13} \mathrm{C}$ resonances were then assigned by the HSQC experiment. The coupling constants $(7.5 \mathrm{~Hz}$ and $8.2 \mathrm{~Hz})$ for the two anomeric protons and the twelve ${ }^{13} \mathrm{C}$ resonances were consistent with two $O$ - $\beta$-glucuronopyranosyl units [30-33]. The additional presence of the two singlets at $\delta 3.63$ and $\delta 3.52 \mathrm{ppm}$ (methoxy groups), which showed cross peaks with the carbonyl groups at $\delta 169.10$ and $\delta 169.17$, respectively, in the HMBC spectrum, suggested the presence of a methyl ester group attached to each of the two glucuronopyranosyl units. The downfield shift of H-2'" ( $\delta 4.62)$ of the terminal glucuronopyranosyl unit indicated acyl substitution. The presence of an AMX system at $\delta 7.03\left(J=2.1 ; \mathrm{H}-2^{\prime \prime \prime \prime}\right), \delta 6.97\left(J=2.1,8.5 ; \mathrm{H}-6^{\prime \prime \prime}\right)$, and $\delta 6.76\left(\mathrm{~J}=8.5 ; \mathrm{H}-5^{\prime \prime \prime \prime}\right)$, and trans-oriented olefinic protons at $\delta 7.43(\mathrm{~J}=15.8 \mathrm{~Hz}, \mathrm{H}-\beta)$ and $\delta 6.24(\mathrm{~J}=15.8 \mathrm{~Hz}, \mathrm{H}-\alpha)$ established the identity of the acyl-group to be (E)-caffeoyl. The cross peaks at $\delta 5.44 / 162.19$ (H-1"/C-7), $\delta 3.52 / 101.42$ $\left(\mathrm{H}-2^{\prime \prime} / \mathrm{C}-1^{\prime \prime \prime}\right), \delta 4.88 / 81.01\left(\mathrm{H}-1^{\prime \prime \prime} / \mathrm{C}-2^{\prime \prime}\right)$, and at $\delta 4.62 / 165.87\left(\mathrm{H}-2^{\prime \prime \prime} / \mathrm{C}=\mathrm{O}\right)$ in the HMBC spectrum of 1 confirmed the linkages between the aglycone, sugar, and $(E)$-caffeoyl moieties (Figure 1 ). The high-resolution $\mathrm{ESI}^{+}-\mathrm{MS}$ spectrum of $\mathbf{1}$ (Figure S9) showed a $[\mathrm{M}+\mathrm{H}]^{+}$ion at $m / z 813.1881$ corresponding to the empirical formula $\mathrm{C}_{38} \mathrm{H}_{37} \mathrm{O}_{20}{ }^{+}$(calc. $813.1878 \mathrm{Da}$ ) in agreement with the dimethyl ester of

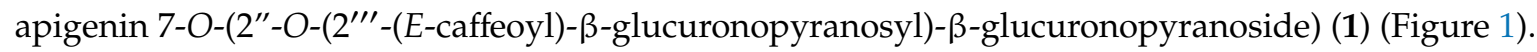


Table $1 .{ }^{1} \mathrm{H}$ and ${ }^{13} \mathrm{C}$ spectral data ( $\delta$ in ppm) for $\mathbf{1}$ and 2 dissolved in DMSO- $d_{6}$ at $25{ }^{\circ} \mathrm{C}$.

\begin{tabular}{|c|c|c|c|c|}
\hline & $1\left({ }^{1} \mathrm{H}\right)$ & $1\left({ }^{13} \mathrm{C}\right)$ & $2\left({ }^{1} \mathrm{H}\right)$ & $2\left({ }^{13} \mathrm{C}\right)$ \\
\hline \multicolumn{5}{|c|}{ Aglycone } \\
\hline 2 & & 164.39 & & 164.66 \\
\hline 3 & $6.85 s$ & 103.25 & $6.73 s$ & 103.31 \\
\hline 4 & & 182.10 & & 182.03 \\
\hline 5 & & 161.28 & & 161.34 \\
\hline 6 & $6.39 d 2.2$ & 99.25 & $6.39 d 2.1$ & 99.29 \\
\hline 7 & & 162.19 & & 162.22 \\
\hline 8 & $6.76 d 2.2$ & 94.44 & $6.73 d 2.1$ & 94.34 \\
\hline 9 & & 157.01 & & 157.06 \\
\hline 10 & & 105.52 & & 105.57 \\
\hline $1^{\prime}$ & & 121.12 & & 121.50 \\
\hline $2^{\prime}$ & 7.94 ' $d{ }^{\prime} 8.8$ & 128.66 & $7.43 \mathrm{br}$ & 119.25 \\
\hline $3^{\prime}$ & $6.95^{\prime} d{ }^{\prime} 8.8$ & 116.15 & & 145.99 \\
\hline $4^{\prime}$ & & 161.50 & & 150.14 \\
\hline $5^{\prime}$ & $6.95^{\prime} d{ }^{\prime} 8.8$ & 116.15 & $6.92 d 8.5$ & 116.18 \\
\hline $6^{\prime}$ & 7.94 'd’ 8.8 & 128.66 & $7.43 d d 2.2,8.5$ & 121.36 \\
\hline \multicolumn{5}{|c|}{ 7-O-glucuronopyranosyl } \\
\hline $1^{\prime \prime}$ & $5.44 d 7.5$ & 97.35 & $5.46 d 7.5$ & 97.37 \\
\hline $2^{\prime \prime}$ & $3.52 m$ & 81.01 & $3.53 \mathrm{~m}$ & 81.07 \\
\hline $3^{\prime \prime}$ & $3.37 m$ & 74.73 & $3.37 m$ & 74.77 \\
\hline $4^{\prime \prime}$ & $3.37 m$ & 71.54 & $3.37 m$ & 71.58 \\
\hline $5^{\prime \prime}$ & $4.19 d 7.5$ & 74.70 & $4.19 d 9.4$ & 74.75 \\
\hline $6 "$ & & 169.10 & & 169.15 \\
\hline $\mathrm{OCH}_{3}$ & $3.63 s$ & 52.09 & $3.63 s$ & 52.14 \\
\hline \multicolumn{5}{|c|}{$2^{\prime \prime}-O-\beta$-glucuronopyranosyl } \\
\hline $1^{\prime \prime \prime}$ & $4.88 d 8.2$ & 101.42 & $4.89 d 8.3$ & 101.46 \\
\hline $2^{\prime \prime \prime}$ & $4.62 d 8.2$ & 73.52 & $4.63 d d 8.3,9.6$ & 73.58 \\
\hline $3^{\prime \prime \prime}$ & $3.47 \mathrm{~m}$ & 73.56 & $3.48+9.6$ & 73.61 \\
\hline $4^{\prime \prime \prime}$ & $3.36 m$ & 72.02 & $3.36+9.6$ & 72.08 \\
\hline $5^{\prime \prime \prime}$ & $3.85 d 8.2$ & 75.37 & $3.85 d 9.6$ & 75.42 \\
\hline $6^{\prime \prime \prime}$ & & 169.17 & & 169.22 \\
\hline $\mathrm{OCH}_{3}$ & $3.52 \mathrm{~s}$ & 51.71 & $3.52 \mathrm{~s}$ & 51.75 \\
\hline \multicolumn{5}{|c|}{$2^{\prime \prime \prime}-O$-caffeoyl } \\
\hline $\mathrm{C}=\mathrm{O}$ & & 165.87 & & 165.94 \\
\hline$\alpha$ & $6.24 d 15.8$ & 114.73 & $6.23 d 15.8$ & 114.75 \\
\hline$\beta$ & $7.43 d 15.8$ & 144.72 & $7.44 d 15.8$ & 144.79 \\
\hline $1^{\prime \prime \prime \prime}$ & & 125.86 & & 125.89 \\
\hline $2^{\prime \prime \prime \prime}$ & $7.03 d 2.1$ & 114.83 & $7.04 d 2.2$ & 114.86 \\
\hline $3^{\prime \prime \prime \prime}$ & & 145.65 & & 145.72 \\
\hline $4^{\prime \prime \prime \prime}$ & & 148.29 & & 148.36 \\
\hline $5^{\prime \prime \prime \prime}$ & $6.76 \mathrm{~m}$ & 115.82 & $6.77 d 8.1$ & 115.87 \\
\hline $6^{\prime \prime \prime \prime}$ & $6.97 d d 2.1,8.5$ & 121.30 & $6.97 d d 2.2,8.1$ & 121.36 \\
\hline
\end{tabular}

$s=$ singlet,$d=$ doublet,$t$-triplet, $d d=$ double doublet, $m=$ multiplet, $b r=$ broad. See Figure 1 for structures. 


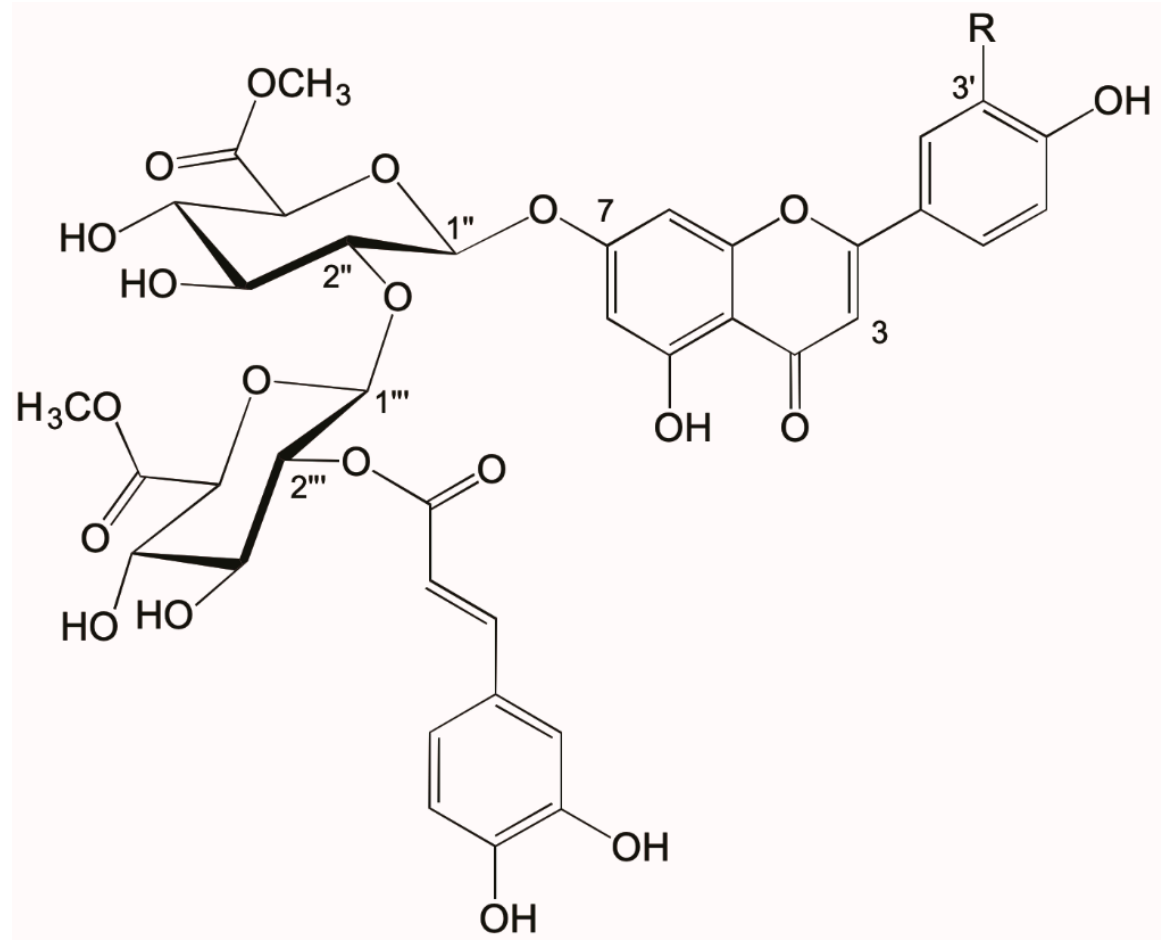

Figure 1. Structures of two new flavonoids $1(R=H)$ and $2(R=O H)$ isolated from aerial parts of Nepeta curviflora.

The NMR resonances of $\mathbf{2}$ were very similar to those of compound $\mathbf{1}$ (Table 1). However, the main differences were shown in the aromatic region where the ${ }^{1} \mathrm{H}$ NMR spectrum of 2 (Figure S11) revealed a $3 \mathrm{H}$ AA'X system at $\delta 7.43\left(\mathrm{H}-2^{\prime}, b r\right), \delta 7.43\left(\mathrm{H}-6^{\prime}, b r\right)$, and $\delta 6.92(J=8.5 \mathrm{~Hz}$; $\left.\mathrm{H}-5^{\prime}\right)$, a $1 \mathrm{H}$ singlet at $\delta 6.73(\mathrm{H}-3)$ and a $2 \mathrm{H} \mathrm{AX}$ system at $\delta 6.73(\mathrm{~d}, J=2.2 \mathrm{~Hz} ; \mathrm{H} 8)$ and $\delta$ $6.39(\mathrm{~d}, J=2.2 \mathrm{~Hz} ; \mathrm{H} 6)$, in accordance with a 7-O-glycosylated luteolin derivative. The cross peaks at $\delta 5.46 / 162.22\left(\mathrm{H}-1^{\prime \prime} / \mathrm{C}-7\right), \delta 3.53 / 101.46\left(\mathrm{H}-2^{\prime \prime} / \mathrm{C}-1^{\prime \prime \prime}\right), \delta 4.89 / 81.07\left(\mathrm{H}-1^{\prime \prime \prime} / \mathrm{C}-2^{\prime \prime}\right)$, and at $\delta 4.63 / 165.94\left(\mathrm{H}-2^{\prime \prime \prime} / \mathrm{C}=\mathrm{O}\right)$ in the HMBC spectrum of 2 (Figure S13) confirmed the linkages between the aglycone, sugar, and $(E)$-caffeoyl moieties (Figure 1). The high-resolution $\mathrm{ESI}^{+}-\mathrm{MS}$ spectrum of 2 (Figure S17) showed a $[\mathrm{M}+\mathrm{H}]^{+}$ion at $\mathrm{m} / \mathrm{z} 829.1830$ corresponding to the empirical formula $\mathrm{C}_{38} \mathrm{H}_{37} \mathrm{O}_{21}{ }^{+}$(calc. $829.1827 \mathrm{Da}$ ) in agreement with the dimethylester form of luteolin 7-O-(2"-O-(2"' -(E-caffeoyl)- $\beta$-glucuronopyranosyl)- $\beta$-glucuronopyranoside) (Figure 1$)$.

Previously, we have reported that the free carboxyl group of glucuronyl moieties of flavonoids readily will be esterified with methanol during extraction and isolation processes involving acidified methanol as solvent [30]. This is in accord with the identification of both 1 and 2 as dimethylesters caused by methylesterfication of the two glucuronyl moieties of these flavonoids. Small amounts of parental 1 and 2 without their methylesters were indeed detected by LC-MS analysis of Sephadex LH-20 fractions of the purified extract of N. curviflora (FigureS S10 and S18).

Antibacterial activity was measured using the agar diffusion method. Sephadex LH-20 fractions containing both 1 and 2 dissolved in DMSO did not reveal antibacterial activity. However, the cruder XAD-7 purified material showed some antibacterial activity, suggesting other compounds in the extract to be considered in future antibacterial activity studies.

\section{Materials and Methods}

\subsection{General}

UV-Vis absorption spectra were recorded on-line during HPLC analysis using a photodiode array detector (HP 1050) (Agilent Technologies, Santa Clara, CA, USA). ${ }^{1} \mathrm{H}(600.13 \mathrm{MHz})$ and ${ }^{13} \mathrm{C}$ 
(150.90 MHz) NMR spectra were obtained on a Bruker Biospin AV-600 MHz instrument equipped with a TCI ${ }^{1} \mathrm{H}_{-}{ }^{13} \mathrm{C} /{ }^{15} \mathrm{~N}$ CryoProbe (Bruker BioSpin, Zürich, Switzerland), and on a Bruker Biospin AV-850 MHz equipped with a CryoProbe (Bruker BioSpin, Zürich, Switzerland). All experiments were recorded at $298 \mathrm{~K}$ and the chemical shift values were set relative to the deutero-methyl ${ }^{13} \mathrm{C}$ signal and the residual ${ }^{1} \mathrm{H}$ signal of the solvent $\left(\left(\mathrm{CD}_{3}\right)_{2} \mathrm{SO}\right)$ at $\delta 39.6$ and $\delta 2.49$, respectively. Low-resolution mass spectra were recorded on a LC-MS system (Agilent Technologies, Santa Clara, CA, USA) consisting of an Agilent 1200 series LC module (binary pump, column compartment/oven, and auto sampler), equipped with an Agilent ZORBAX SB-C 18 (RRHT $2.1 \times 50 \mathrm{~mm}, 1.8 \mu \mathrm{m}$ ), with an Agilent 6420A mass spectrometer equipped with a triple quadrupole (QqQ configuration) mass analyzer using electrospray ionization (ESI) as detector.

High-resolution mass spectrometry $\left(\mathrm{ESI}^{+} / \mathrm{TOF}\right)$, spectra were recorded using a JEOL AccuTOF JMS-T100LC instrument (JEOL, Peabody, USA) in combination with an Agilent Technologies 1200 Series HPLC system. A Zorbax Eclipse-C18 (Agilent Technologies, Santa Clara, CA, USA) $(50 \times 2.1 \mathrm{~mm}$, length $\times$ i.d., $1.8 \mu \mathrm{m})$ column was used for separation. Two solvents, $\mathrm{A}\left(\mathrm{H}_{2} \mathrm{O}+0.2 \% \mathrm{HCOOH}, v / v\right)$ and $\mathrm{B}$ (acetonitrile $+0.2 \% \mathrm{HCOOH}, v / v$ ), were used for elution. The following solvent compositions were used: $0 \mathrm{~min}(0 \% \mathrm{~B}), 0-2 \mathrm{~min}$ ( 0 to $10 \% \mathrm{~B}$, linear gradient), $2-15 \mathrm{~min}$ (10 to $80 \% \mathrm{~B}$, linear gradient). The flow rate was $0.4 \mathrm{~mL} / \mathrm{min}$ and the temperature was kept at $60^{\circ} \mathrm{C}$.

\subsection{Isolation of Flavones}

The aerial parts of Syrian catnip (stems, leaves, and flowers) were collected in May 2016 from the close surrounding area of Birzeit University, Palestine (Coordinates: Latitude: $31^{\circ} 57^{\prime} 18.76^{\prime \prime} \mathrm{N}$; Longitude: $35^{\circ} 10^{\prime} 30.32^{\prime \prime} \mathrm{E}$ ). The collected plant material was dried and thereafter stored for approximately one month. The dried aerial part $(755 \mathrm{~g})$ was extracted three times over night at $4{ }^{\circ} \mathrm{C}$, with $5 \mathrm{~L} 10 \% \mathrm{H}_{2} \mathrm{O}$ in $\mathrm{MeOH}(v / v$; containing $0.5 \%$ trifluoroacetic acid, TFA). The combined extract was concentrated under reduced pressure in order to remove methanol. The nonpolar compounds were removed by partition against hexane. Approximately $1 / 3$ of the resulting aqueous phase was subjected to Amberlite XAD-7 column chromatography. Part of the XAD-7 purified extract (2.34 g) was further purified and separated on a $100 \times 5 \mathrm{~cm}$ Sephadex LH-20 column using acetonitrile- $-\mathrm{H}_{2} \mathrm{O}$ :TFA (10:90:0.2; $v / v)$ and $\mathrm{MeOH}-\mathrm{H}_{2} \mathrm{O}$ :TFA $(80: 20: 0.2 ; v / v)$ as mobile phase with a flow rate of $4 \mathrm{~mL} / \mathrm{min}$ (Supporting Information, Table S4).

A mixture of compounds 1, 2, and 4 was obtained in the combined fractions 25 and 26 achieved by Sephadex LH-20 chromatography (Table S4). Pure compounds 1, 2, and 4 were then isolated from fractions 25 and 26 by preparative HPLC. Pure compound 3 was eluted in Sephadex LH-20 fraction 33 (Table S4). The isolation of compounds 5 and $\mathbf{6}$ was based on the extraction of $195 \mathrm{~g}$ dried flowers of $\mathrm{N}$. curviflora followed by the same purification and separation steps as indicated above. The dried XAD-7 purified extract $(2.31 \mathrm{~g}$ ) was fractionated by Sephadex LH-20 chromatography, and pure 5 and $\mathbf{6}$ were obtained in fractions 27 and 38, respectively (Supporting Information, Table S5).

\subsection{Preparative HPLC}

Preparative HPLC was performed using a Gilson 321 preparative HPLC equipped with a UV detection (Dionex UltiMate 3000 Variable Wavelength Detector) (Dionex Corporation, Sunnyvale, CA, US). The system was equipped with an Econosil C18 column $(250 \mathrm{~mm} \times 22 \mathrm{~mm}$; length $\times$ I.D., $5.0 \mu \mathrm{m}$; Fortis Technologies Ltd., Neston, UK). The elution protocol consisted of solvents $\mathrm{A}, \mathrm{H}_{2} \mathrm{O}$ containing $0.5 \%$ TFA $(v / v)$ and B, acetonitrile containing $0.5 \%$ TFA $(v / v)$. The following gradient was used: $100 \% \mathrm{~A}$ in $0-5 \mathrm{~min}, 10 \% \mathrm{~B}$ (isocratic elution) for the next $46 \mathrm{~min}$ (6-52 $\mathrm{min}$ ), $20 \% \mathrm{~B}$ (isocratic elution) for the next $12 \mathrm{~min}$ (53-65 $\mathrm{min}$ ), 50\% B (isocratic elution) for the next four minutes (66-70 $\mathrm{min}$ ), and then back to the starting conditions $\left(100 \% \mathrm{~A}\right.$, isocratic elution) in $4 \mathrm{~min}(71-75 \mathrm{~min})$. The flow rate was $12.0 \mathrm{~mL} \mathrm{~min}{ }^{-1}$. 


\subsection{Analytical HPLC}

Analytical HPLC was performed using Agilent 1100 HPLC system (Agilent Technologies, Santa Clara, CA, USA) equipped with a HP 1050 diode array detector and with an ODS-Hypersil column $\left(20 \times 0.5 \mathrm{~cm}\right.$, length $\times$ i.d., $5 \mu \mathrm{m}$; Supelco, Bellefonte, PA, USA), using the solvents $\mathrm{A}, \mathrm{H}_{2} \mathrm{O}$ containing $0.5 \%$ TFA $(v / v)$ and $\mathrm{B}$, acetonitrile containing $0.5 \%$ TFA $(v / v)$. The following gradient (B in A) was used: 10 to $14 \% \mathrm{~B}$ in $0-10 \mathrm{~min}, 14 \% \mathrm{~B}$ (isocratic elution) for the next $4 \mathrm{~min}, 14$ to $40 \% \mathrm{~B}$ (linear gradient) from $14-32 \mathrm{~min}, 40 \% \mathrm{~B}$ (isocratic elution) from 32-43 min, followed by a linear gradient $40 \%$ $\mathrm{B}-10 \% \mathrm{~B}$ for $3 \mathrm{~min}$ to re-establish the starting conditions. The flow rate was $1.0 \mathrm{~mL} \mathrm{~min}^{-1}$.

\subsection{Biological Activity}

The antibacterial activities of Sephadex LH-20 fractions containing both $\mathbf{1}$ and 2, and XAD-7 purified material, were investigated against five gram-positive (Staphylococcus aureus, Micrococcus luteus, Bacillus subtilis, Enterococcus faecalis, and Staphylococcus epidermidis) and four gram-negative (Escherichia coli, Klebsiella pneumonia, Proteus mirabilis, and Proteus aeruginosa) bacteria. The antibacterial test was carried out by using the agar diffusion method. The sterile saline was prepared by dissolving $0.5 \mathrm{~g}$ of $\mathrm{NaCl}$ in $500 \mathrm{~mL}$ of water $(0.1 \%$ of $\mathrm{NaCl})$ before this solution was autoclaved. The single bacterial colonies were dissolved in the sterile saline until the turbidity of the suspended cells reached the McFarland 0.5 standard. The bacterial inocula were spread on the surface of Mueller-Hinton nutrient agar using a sterile cotton swab. Then, the wells $(6 \mathrm{~mm}$ in diameter) in the agar plate were made by using Sterile glassy borer [34,35]. The samples were dissolved in DMSO in concentrations of $6 \mathrm{mg} / \mathrm{mL}$, and $25 \mu \mathrm{L}$ of each were added into their respective wells before the plates were incubated at $37^{\circ} \mathrm{C}$ for 12-24 h. Gentamycin (G) and Erythromycin (E) were used as positive controls, while DMSO was used as negative control. The activities of the samples were determined by measuring the inhibition zone diameter in millimeter. The results were determined by calculating the average of three trials.

\section{Conclusions}

In this investigation, individual phenolic constituents of the aerial parts of Syrian catnip have been characterized on the basis of extensive spectroscopic analyses. Two new flavonoids ( $\mathbf{1}$ and $\mathbf{2})$ along with two known flavonoids (5 and $\mathbf{6}$ ) and the methylesters of rosmarinic acid (3) and caffeic acid (4) have been identified. Flavonoids glycosylated with glucuronic acid have previously been reported from several Nepeta spp. [36-38]. However, the findings of $\mathbf{1}$ and $\mathbf{2}$ in N. curviflora are the first report of acylated flavone glucuronides in the genus Nepeta, which might have chemotaxonomic significance within the genus.

Supplementary Materials: The following are available online. Figure S1: $1 \mathrm{D}^{1} \mathrm{H}$ NMR spectrum of apigenin 7-O-(2"-O-(2'"'-(E-caffeoyl)- $\beta$-glucuronopyranosyl)- $\beta$-glucuronopyranoside) (1). Figure S2: $1 \mathrm{D}^{13} \mathrm{C}$ CAPT NMR spectrum of apigenin 7-O-(2"-O-O(2"'-(E-caffeoyl)- $\beta$-glucuronopyranosyl)- $\beta$-glucuronopyranoside) (1). Figure

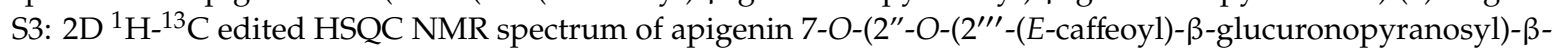
glucuronopyranoside) (1). Figure S4: $2 \mathrm{D}^{1} \mathrm{H}_{-}{ }^{13} \mathrm{C}$ HMBC NMR spectrum of apigenin $7-\mathrm{O}-\left(2^{\prime \prime}-\mathrm{O}-\left(2^{\prime \prime \prime}-(E-\right.\right.$-caffeoyl $)-\beta-$ glucuronopyranosyl)- $\beta$-glucuronopyranoside) (1). Figure S5: $2 \mathrm{D}{ }^{1} \mathrm{H}_{-}{ }^{13} \mathrm{C}$ HSQC-TOCSY NMR spectrum of apigenin $7-O-\left(2^{\prime \prime}-O-\left(2^{\prime \prime \prime}-\left(E\right.\right.\right.$-caffeoyl)- $\beta$ - glucuronopyranosyl)- $\beta$-glucuronopyranoside) $(1)$. Figure $S 6: 2 \mathrm{D}^{1} \mathrm{H}^{-13} \mathrm{C}$ H2BC NMR spectrum of apigenin 7-O-(2"-O-(2'"'-(E-caffeoyl)- $\beta$-glucuronopyranosyl) $-\beta$ - glucuronopyranoside $)$ (1). Figure S7: $2 \mathrm{D}^{1} \mathrm{H}^{-1} \mathrm{H}$ COSY NMR spectrum of apigenin 7-O-(2"-O-(2'"'-(E-caffeoyl)- $\beta$-glucuronopyranosyl)-

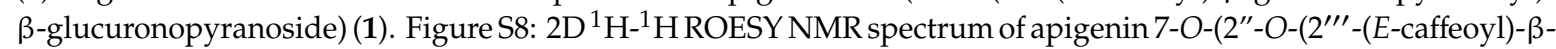
glucuronopyranosyl)- $\beta$-glucuronopyranoside) (1). Figure S9: HR Mass spectrum of the dimethylester form

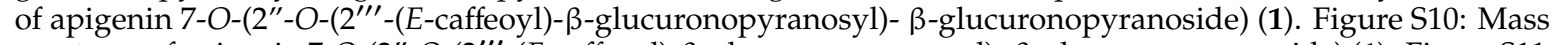
spectrum of apigenin 7-O-(2"-O-(2"')-(E-caffeoyl)- $\beta$-glucuronopyranosyl)- $\beta$-glucuronopyranoside) (1). Figure S11: $1 \mathrm{D}^{1} \mathrm{H}$ NMR spectrum of luteolin 7-O-(2"-O-(2"')-(E-caffeoyl)- $\beta$ - glucuronopyranosyl)- $\beta$-glucuronopyranoside) (2). Figure S12: $1 \mathrm{D}^{13} \mathrm{C}$ CAPT NMR spectrum of luteolin 7-O-(2"-O-(2'"-(E-caffeoyl)- $\beta$-glucuronopyranosyl)$\beta$-glucuronopyranoside) (2). Figure S13: $2 \mathrm{D}^{1} \mathrm{H}_{-}{ }^{13} \mathrm{C}$ HMBC NMR spectrum of luteolin 7-O-(2"'-O-(2'"'-(E-caffeoyl)$\beta$-glucuronopyranosyl)- $\beta$-glucuronopyranoside) (2). Figure S14: $2 \mathrm{D}^{1} \mathrm{H}^{-13} \mathrm{C}$ edited HSQC NMR spectrum of

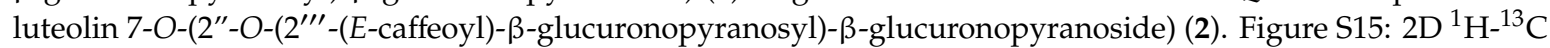

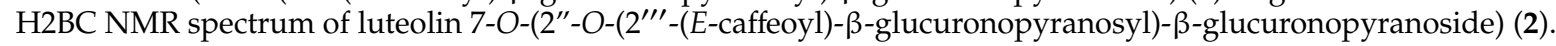


Figure S16: 2D ${ }^{1} \mathrm{H}_{-}{ }^{1} \mathrm{H}$ COSY NMR spectrum of luteolin 7-O-(2"-O-(2'"'-(E-caffeoyl)- $\beta$-glucuronopyranosyl)$\beta$-glucuronopyranoside) (2). Figure S17: HR mass spectrum of the methyl ester form of luteolin 7-O-(2"-O-(2"' -(E-caffeoyl)- $\beta$-glucuronopyranosyl)- $\beta$-glucuronopyranoside) (2). Figure S18: Mass spectrum of luteolin 7-O-(2"-O-(2"' -(E-caffeoyl)- $\beta$-glucuronopyranosyl)- $\beta$-glucuronopyranoside) (2). Table S1: Chromatographic (HPLC) and spectral (UV and MS) data recorded for 1-6 from Nepeta curviflora. Table S2: ${ }^{1} \mathrm{H}$ and ${ }^{13} \mathrm{C}$ spectral data (ppm) and coupling constants $(\mathrm{Hz})$ for compounds 3 and 4 dissolved in DMSO-D6 at $25{ }^{\circ} \mathrm{C}$. Table S3: ${ }^{1} \mathrm{H}$ and ${ }^{13} \mathrm{C}$-NMR chemical shift values of apigenin (5) and apigenin $7-O-\beta$-glucuronopyranoside (6) in DMSO-D 6 at $298 \mathrm{~K}$. Table S4: Solvent composition and elution volumes used for separation of XAD-7 purified extract of aerial parts of Nepeta curviflora using a $100 \times 5 \mathrm{~cm}$ Sephadex LH-20 column. The flow rate was $4 \mathrm{~mL} / \mathrm{min}$. Table S5: Composition and elution volumes used for separation of XAD-7 purified extract of flowers of Nepeta curviflora using a $100 \times 5 \mathrm{~cm}$ Sephadex LH-20 column. The flow rate was $4 \mathrm{~mL} / \mathrm{min}$. Table S6: In-vitro anti-bacterial activity data for compound 1 and 2 and for the XAD purified materials against gram-negative bacteria. Inhibition zone diameter is in millimetre. Table S7: In-vitro anti-bacterial activity data for compounds 1 and 2 and for the XAD purified materials against gram positive bacteria. Inhibition zone diameter is in millimeter.

Author Contributions: S.R., H.A.A., Ø.M.A., and T.F. planned, and designed the project. S.R. and M.R. isolated the pure natural products. K.H.E. performed LC-MS analysis. T.F. recorded NMR spectra of isolated fractions. S.R. and T.F. determined the structures of the isolated compounds. S.R., T.F., and Ø.M.A. wrote the manuscript. All authors have read and agreed to the published version of the manuscript.

Funding: This research received no external funding.

Acknowledgments: We acknowledge Bjarte Holmelid (Dept. of Chemistry, University of Bergen) for recording of high-resolution mass spectra. Azmi Doudin and Asem Mubarak (both Department of Chemistry, Birzeit University) are acknowledged for technical assistance, Ibrahim Shalash (Department of Chemistry, Birzeit University) for the help with the analytical HPLC and the different chemicals used in this work. Khaled Sawalha (Botanist and Director of AQU Herbarium) and the Union of Agricultural Work Committees (UAWC) are acknowledged for storing voucher specimen of $N$. curviflora. This work was partly supported by the Research Council of Norway through the Norwegian NMR Platform, NNP (226244/F50). The authors thank the office of Vice-President for Academic Affairs at Birzeit University for financial support.

Conflicts of Interest: The authors declare no conflict of interest.

\section{References}

1. Jamzad, Z.; Grayer, R.J.; Kite, G.C.; Simmonds, M.S.J.; Ingrouille, M.; Jalili, A. Leaf surface flavonoids in Iranian species of Nepeta (Lamiaceae) and some related genera. Biochem. Syst. Ecol. 2003, 31, 587-600. [CrossRef]

2. Ali, L.; Ali, S.; Rizvi, T.S.; Khan, A.; Hassan, Z.; Al-Harrasi, A.; Hussain, J. Antioxidant Flavonoids from Nepeta floccosa Benth. Rec. Nat. Prod. 2015, 9, 567-571.

3. Baser, K.H.C.; Kirimer, N.; Kurkcuoglu, M.; Demirci, B. Essential oils of Nepeta species growing in Turkey. Chem. Nat. Compd. 2000, 36, 356-359. [CrossRef]

4. Dabiri, M.; Sefidkon, F. Composition of essential oil of Nepeta crassifolia Boiss and Buhse. Flav. Fragr. J. 2003, 18, 225-227. [CrossRef]

5. Rapisarda, A.; Galati, E.M.; Tzakou, O.; Flores, M.; Miceli, N. Nepeta sibthorpii Bentham (Lamiaceae): Micromorphological analysis of leaves and flowers. Farmaco 2001, 56, 413-415. [CrossRef]

6. Naghibi, F.; Mosaddegh, M.; Motamed, S.M.; Ghorbani, A. Labiatae family in folk medicine in Iran: From Ethnobotany to Pharmacology. Iran. J. Pharm. Res. 2005, 2, 63-79.

7. Firoozabadi, A.; Kolouri, S.; Zarshenas, M.; Salehi, A.; Mosavat, S.H.; Dastgheib, S.A. Efficacy Nepeta menthoides Boiss and Buhse freeze-dried aqueous extract on anxiety of patients with depression: A double-blind randomized controlled clinical trial. Iran J. Med. Sci. 2016, 41, 164-170. [CrossRef]

8. Dienaitèa, L.; Pukalskienèa, M.; Matiasb, A.A.; Pereirab, C.V.; Pukalskasa, A.; Venskutonisa, P.R. Valorization of six Nepeta species by assessing the antioxidant potential, phytochemical composition and bioactivity of their extracts in cell cultures. J. Funct. Foods 2018, 45, 512-522. [CrossRef]

9. Barhoumi, L.M.; Al-Jaber, H.I.; Abu Zarga, M.H. Volatile Organic Compounds and Essential Oil Composition of Selected Organs of Nepeta curviflora Collected from two Region in Jordan. Jord. J. Chem. 2017, 12, 101-112.

10. Bernardi, M.M.; Kirsten, T.B.; Salzgeber, S.A.; Ricci, E.L.; Romoff, P.; Guilardi Lago, J.H.; Lourenc, L.M. Antidepressant-like effects of an apolar extract and chow enriched with Nepeta cataria (catnip) in mice. Psychol. Neurosci. 2010, 3, 251-258. [CrossRef] 
11. Hadi, N.; Sefidkon, F.; Shojaeiyan, A.; Šiler, B.; Jafari, A.A.; Mišić, D. Phenolic's composition in four endemic Nepeta species from Iran cultivated under experimental field conditions: The possibility of the exploitation of Nepeta germplasm. Ind. Crop. Prod. 2017, 95, 475-484. [CrossRef]

12. Joshi, N.; Sah, G.C. GC-MS analysis and antimicrobial activity of essential oil of Nepeta coerulescens. Int. J. Res. Pharm. Pharm. 2014, 3, 68-71.

13. Kaviarasan, S.; Sundarapandiyan, R.; Anuradha, C.V. Protective action of fenugreek (Trigonella foenum graecum) seed polyphenols against alcohol-induced protein and lipid damage in rat liver. Cell. Biol. Toxicol. 2008, 24, 391-400. [CrossRef]

14. Mahboubi, M.; Kazempour, N.; Ghazian, F.; Taghizadeh, M. Chemical composition: Antioxidant and antimicrobial activity of Nepeta persica Boiss essential oil. Herba Pol. 2011, 57, 62-71.

15. Nestorović, J.; Mišić, D.; Šiler, B.; Soković, M.; Glamočlija, J.; 'Cirić, A.; Maksimović, V.; Grubišić, D. Nepeta lactone content in shoot cultures of three endemic Nepeta species and the evaluation of their antimicrobial activity. Fitoterapia 2010, 81, 621-626. [CrossRef]

16. Süntar, I.; Nabavi, S.M.; Barreca, D.; Fischer, N.; Efferth, T. Pharmacological and chemical features of Nepeta L. genus: Its importance as a therapeutic agent. Phytother. Res. 2018, 32, 185-198.

17. Mišić, D.; Šiler, B.; Gašić, U.; Avramov, S.; Živković, S.; Nestorović Živković, J.; Milutinović, M.; Tešičć, Ž. Simultaneous UHPLC/DAD/(+/-) HESI-MS/MS analysis of phenolic acids and Nepeta lactones in methanol extracts of Nepeta species: A possible application in chemotaxonomic studies. Phytochem. Anal. 2015, 26, 72-85.

18. Formisano, C.; Rigano, D.; Senatore, F. Chemical constituents and biological activities of Nepeta species. Chem. Biodivers. 2011, 8, 1783-1818. [CrossRef]

19. Lee, S.Y.; Lee, C.Y.; Eom, S.H.; Kim, Y.K.; Park, N.I.; Park, S.U. Rosmarinic acid production from transformed root cultures of Nepeta Cataria L. Sci. Res. Essays 2010, 5, 1122-1126.

20. Mihaylova, D.; Georgieva, L.; Pavlov, A. In vitro antioxidant activity and phenolic composition of Nepeta cataria L. extracts. Int. J. Agric. Sci. Tech. 2013, 1, 74-79.

21. Modnicki, D.; Tokar, M.; Klimek, B. Flavonoids and phenolic acids of Nepeta cataria L: Var citriodora (Becker) balb (Lamiaceae). Acta. Pol. Pharm. 2007, 64, 247-252.

22. Trivellini, A.; Lucchesini, M.; Maggini, R.; Mosadegh, H.; Villamarin, T.S.S.; Vernieri, P.; Mensuali-Sodi, A.; Pardossi, A. Lamiaceae phenols as multifaceted compounds: Bioactivity, industrial prospects and role of positive-stress. Ind. Crop. Prod. 2016, 83, 241-254. [CrossRef]

23. Al-Qudah, M.A. Antioxidant activity and chemical composition of essential oils of fresh and dried Jordanian Nepeta curviflora Boiss. J. Biol. Act. Prod. Nat. 2016, 6, 101-111.

24. Mancini, E.; Arnold, N.A.; Feo, V.D.; Formizano, C.; Rigano, D.; Piozzi, F.; Senatore, F. Phytotoxic effects of essential oils of Nepeta curviflora Boiss and Nepeta nuda L subsp albiflora growing wild in Lebanon. J. Plant. Inter. 2009, 4, 253-259.

25. Musso, L.; Scaglia, B.; Al Haj, G.; Apostolides, N.A.; Adani, F.; Scarì, G.; Dallavalle, S.; Iriti, M. Chemical Characterization and Nematicidal Activity of the Essential Oil of Nepeta nuda L. ssp pubescens and Nepeta curviflora Boiss from Lebanon. J. Essent. Oil Bear. Pl. 2017, 20, 1424-1433. [CrossRef]

26. Al-Bakri, A.G.; Afifi, F.U. Evaluation of antimicrobial activity of selected plant extracts by rapid XTT colorimetry and bacterial enumeration. J. Microbiol. Meth. 2007, 68, 19-25. [CrossRef]

27. Barbour, E.K.; Al Sharif, M.; Sagherian, V.K.; Habre, A.N.; Talhouk, R.S.; Talhouk, S.N.J. Screening of selected indigenous plants of Lebanon for antimicrobial activity. J. Ethnopharmacol. 2004, 93, 1-7. [CrossRef]

28. Cigremis, Y.; Ulukanli, Z.; Ilcim, A.; Akgoz, M. In vitro antioxidant and antimicrobial assays of acetone extracts from Nepeta meyeri Bentham. Eur. Rev. Med. Pharm. Sci. 2010, 14, 661-668.

29. Proestos, C.; Lytoudi, K.; Mavromelanidou, O.; Zoumpoulakis, P.; Sinanoglou, V. Antioxidant Capacity of Selected Plant Extracts and Their Essential Oils. Antioxidants 2013, 2, 11-22. [CrossRef]

30. Fossen, T.; Slimestad, R.; Øvstedal, D.O.; Andersen, Ø.M. Covalent anthocyanin-flavonols complexes from flowers of chive, Allium schoenoprasum. Phytochemistry 2000, 54, 317-323. [CrossRef]

31. Fossen, T.; Andersen, Ø.M. Spectroscopic techniques applied to flavonoids. In Flavonoids: Chemistry, Biochemistry and Applications; Andersen, Ø.M., Markham, K.R., Eds.; CRC Press: Boca Raton, FL, USA, 2006; pp. 37-142.

32. Kowalska, I.; Stochmal, A.; Kapusta, I.; Janda, B.; Pizza, C.; Piacente, S.; Oleszek, W. Flavonoids from barrel medic (Medicago truncatula) aerial parts. J. Agric. Food Chem. 2007, 55, 2645-2652. [CrossRef] 
33. Stochmal, A.; Simonet, A.M.; Macias, F.A.; Oleszek, W. Alfalfa (Medicago sativa L.) flavonoids. 2. Tricin and chrysoeriol glycosides from aerial parts. J. Agric. Food Chem. 2001, 49, 5310-5314. [CrossRef]

34. Parada, J.; Atria, A.N.; Wiese, G.; Rivas, E.; Corsini, G. Synthesis, characterization and antibacterial activity of cobalt (III) complex with phenanthroline and Maltose. J. Chil. Chem. Soc. 2014, 59, 2636-2639. [CrossRef]

35. Rahman, M.M.; Sheikh, M.M.I.; Sharmin, S.A.; Islam, M.S.; Rahman, M.A.; Rahman, M.M.; Alam, M.F. Antibacterial activity of leaf juice and extracts of Moringa oleifera Lam. Against some human patho-genic bacteria. Chiang Mai University. J. Nat. Sci. 2009, 8, 219-228.

36. Güvenalp, Z.; Özbek, H.; Kuruüzüm-Uz, A.; Kazaz, C.; Demirezer, L.Ö. Secondary metabolites from Nepeta heliotropifolia. Turk. J. Chem. 2009, 33, 667-675.

37. Olennikov, D.N.; Akobirshoeva, A.A. Flavonoids and phenylpropanoids of Nepeta glutinosa and Ziziphora Pamiroalaica. Chem. Nat. Compd. 2016, 52, 909-912. [CrossRef]

38. Tomas-Barberan, F.A.; Gil, M.I.; Ivanchev, S.; Tomas-Lorente, F. External and vacuolar flavonoids from Nepeta transcaucasica. Biochem. Syst. Ecol. 1992, 20, 589-590. [CrossRef]

Sample Availability: Samples of the compounds can be obtained from the authors.

(C) 2020 by the authors. Licensee MDPI, Basel, Switzerland. This article is an open access article distributed under the terms and conditions of the Creative Commons Attribution (CC BY) license (http://creativecommons.org/licenses/by/4.0/). 